\title{
Review of Rutger Claassen's Capabilities in a Just Society: A Theory of Navigational Agency. Cambridge: Cambridge University Press, 2018, 264 pp.
}

\author{
HENRY S. RICHARDSON \\ Georgetown University
}

Rutger Claassen's bold, ambitious, and often insightful book vigorously sets out to improve on existing versions of the capability approach. He engages mainly with the version developed by Martha Nussbaum, with its well-known list of central capabilities, threshold levels of which are to be guaranteed by governments as a matter of minimal justice. While he retains a sufficientarian subsistence standard, he offers a more complete account of socio-economic justice. His principal criticism of Nussbaum's view is that, even in its later versions, it invokes a contentious conception of human flourishing or well-being, thus exhibiting a problematic form of perfectionism. The book's resourceful effort to avoid this problem motivates its principal departures from Nussbaum and spurs its major novelty: its focus on the concept of "navigational agency", which is understood as the capacity to step back reflectively from the social practices one is participating in to choose "freely and autonomously" which ones to participate in and to resolve conflicts among one's practices (61). Definitionally, it stands in contrast to "participational agency", which we exercise by operating within a practice's norms.

Claassen accepts that no liberal theory can completely avoid substantive commitments about the content of the good; but he argues that perfectionism becomes problematic under two conditions. To describe the first, Claassen cites Rawls' unduly neglected discussion of Wicksell's unanimity criterion, which restricts the government's use of taxation to pay for things neither mandated by justice nor accepted as good by all citizens (26). ${ }^{1}$ Of course, Nussbaum does hold that justice requires governments to guarantee citizens threshold levels of the central capabilities. Yet the issue of how to pay for doing this, Claassen argues, at least raises a question about the legitimacy of the effort. Second, he suggests that

\footnotetext{
${ }^{1}$ John Rawls (1999, 249-251), cited by Claassen at p. 26. He there ignores Rawls' setting aside, in the cited passage, of what is required by justice.
} 
perfectionism is problematic also when it disrespects the diversity of citizens' value commitments. Nussbaum's detailed list of central capabilities, he argues, can do this either by what it includes or by what it excludes.

Claassen's proposal for how a liberal view can avoid problematic perfectionism hinges on establishing that navigational agency stands above the fray as no mere value because it grounds "a regulative principle" (42). For Claassen's liberal view, as for Nussbaum's, autonomy is a central value. Yet it makes all the difference, he claims, whether "autonomous agency is a value on the same plane as other values" (41). If it were, awkward "balancing problems" would arise (42).

Offering what he dubs a "transcendental argument", Claassen argues that navigational agency does stand above the fray (73). We might also think of this argument as defending a novel sort of agency-based constitutivism to contend with Christine Korsgaard's (2009) or Michael Smith's (2013). Claassen argues that rational agents "will necessarily understand themselves as navigational agents" (86). I will shortly attend to the details of this argument; but, first we should examine what it would deliver, if successful.

Given Claassen's commitment to the capability approach, it delivers an "agency-based capability theory" (48) - an ABC theory, for short. People need many capabilities simply to function as participative agents. Yet the $\mathrm{ABC}$ theory naturally stresses the capabilities that are involved in exercising navigational agency. Claassen puts his $\mathrm{ABC}$ theory to good use in many ways. To begin with, it frames his general characterization of justice, which, he tells us, is the sole virtue of political institutions (12): "Justice", Claassen writes, "is normally (and correctly) understood as being about equality in some dimension" (66). Perhaps this oversimplifies the truth about justice. ${ }^{2}$ Indeed, Claassen himself has more complicated things to say about justice. Still, it can be important for a theory of justice to indicate what needs to be equalized. The ABC theory holds that "navigational agency, but not participational agency [is] the right equalisandum" (67). Taking a stand against relational egalitarian views such as Elizabeth Anderson's (1999), Claassen argues that productive efficiency can justify hierarchical organization and that arenas in which people compete for status can help develop their participants' agential skills (123ff.). The

\footnotetext{
${ }^{2}$ Amartya K. Sen's (1980) “Equality of What?" gave this simple thought much momentum; but Sen has himself pulled back from it-for example, in The Idea of Justice (Sen 2009). Rawls $(1999,112)$, for his part, is happier with the French revolution's trio, liberty, equality, and fraternity.
} 
$\mathrm{ABC}$ theory points us instead to the significance of "avoiding [...] domination, marginalization, or oppression" (124). These interfere with navigational equality by blocking some citizens from exiting or reforming social practices (69).

In the book's third and final part, Claassen elaborates the $\mathrm{ABC}$ theory's implications for civil rights, socio-economic justice, and political justice. He frames civil rights in terms of the capacities of entering or exiting a given social practice. Navigational agency's primacy gives priority to the latter. The rights of entering or becoming included in a practice, he argues, are more complicated. An individual's liberty to associate with whom they please "trumps" the equal standing of autonomous agents (161), thereby reminding us that equality is not all there is to justice. Yet participation in certain social practices-"firms, unions, political parties, media outlets which cover political debates, etc." (160)-is contingently necessary for developing capacities of navigational agency.

The chapter on socio-economic justice invokes the $\mathrm{ABC}$ theory to motivate not only minimal capability thresholds, as in Nussbaum's theory, but also limits on inequalities of income and wealth. Participational agency undergirds Claassen's sufficientarian standard for the various capabilities that enable normal functioning within social practices. Because equal navigational agency requires an absence of oppression and domination, we may generalize Rawls' argument for the fair value of the equal political liberties to explain why inequalities of income and wealth must be kept within narrow bounds. ${ }^{3}$

Finally, in the chapter on political rule, Claassen amends Kant's view that people in a state of nature must enter into a civil society in order to see to it that rights are rendered sufficiently determinate that they may be enforced and acted upon. His amendment substitutes individuals' rights to navigational agency for Kant's focus on property rights (200). Claassen also adds that, beyond the duty to exit the state of nature, there is also an abiding duty to work to maintain the fabric of rights. Although he pays some lip service to "the will of the people" (207), what matters to him are the rights of navigational agency. To shield them, he comments, "democratic protections may or may not be more robust than the ones offered by benevolent dictatorships" (206). What he calls "the duty of participation" is simply "a duty to cooperate to create and uphold a legalpolitical system" (208).

\footnotetext{
${ }^{3}$ See, for example, Rawls $(2001,161)$.
} 
I have been able to give only the barest indication of the impressive diversity of ways in which, in these later chapters, the book brings the $A B C$ theory to bear on matters of justice. Having these in mind, it is now time to circle back to the argument that is meant to justify that theory.

A transcendental argument normally starts with a central fact of our experience and lays out (some of the) necessary conditions of its possibility. Instead, Claassen gives us an argument that is closer in form to the agency-based constitutivist views mentioned earlier. These theories do not work from basic facts about our existence. Instead, they work from ideals, such as those of rationality, that somehow attach to our status as agents. For example, it is common to claim that they are embedded in agency's 'constitutive aim'. Drawing on an ideal of rationality, Claassen's core argument is creative and original in that it works disjunctively with both participational and navigational agency. Unlike many constitutivists who appeal only to a priori assumptions, Claassen freely invokes empirical ones. First, he assumes, quite reasonably, that there are social practices and that all human agents with the capacity to reason participate in them. Second, he assumes, again plausibly, that while some are "mere participational agents", there are also some who are also exercising navigational agency (92). Third, and more contentiously, he assumes that those who are exercising navigational agency enjoy superior social status to those who are not (92). Why must that be so? We must allow that the capabilities definitive of navigational agency are socially supported. This implies that navigational agents will have opportunities to exit, enter, and reform social practices. These capabilities in turn will support a valuable social status; but is it necessarily higher than that of all mere participational agents? Claassen writes that "an inferior agent considers that her practical identity is given by her social role" (93). But take the case of France in the time of the Sun King. Louis XIV and the nobles in his court were born into roles in the monarchy, which afforded them no right of exit. The king's own powers to induce reforms lower down constituted no reform in his own practice, that of absolute monarchy. There was room in the Bourbon court for navigational agents, functionaries floating in and out like seventeenth-century counterparts of today's McKinsey MBA's. Yet, while these navigational agents probably enjoyed decent lives, their status fell well below that of the many mere participational agents who made up the aristocracy. Still, let us allow also this third assumption and consider what follows. 
Claassen argues that the ideologies that sustained past inegalitarian societies are rationally indefensible and that, at least once the merely participational agents are given some education-another empirical proviso-they will realize this and, in doing so, will realize that they could become navigational agents. Having reached that point, any mere participational agent "would be irrational if he would not claim a right to [this] potentiality" (97). This conclusion, as Claassen sees it, is "based on a necessary-prudential reason": becoming a navigational agent will give them a wider range of options, and hence "more benefits" (99). But this pro tanto benefit is apt to be outweighed by countervailing effects. We will need to look more closely to see where it holds all things considered. It is not prudentially irrational to give up a pro tanto good for what is better all things considered. Louis XIV's nobles could rationally have avoided any rational questioning of the system from which they benefited, especially if doing so would have brought their loyalty into question. Or consider the "emancipated slaves [and] working women" about whom Claassen writes that "if you give [them] access to education, more money and political power, they can change status and become superior agents themselves" (96). Yes; but this is a wishful hypothetical. In the U.S., the newly emancipated well recognized the injustice of their oppression, and so could have entered into navigational agency; but they were not given sufficient resources or power to shelter their attempts to claim navigational freedom against vicious reprisals. For them to demand their rights as equals was to risk being stigmatized as 'uppity' by the still-dominant whites, who lynched thousands for such threats to the persisting racist order. In these circumstances, it would have been prudentially rational for most of those released from bondage to lay low and refrain from claiming the rights of navigational agency.

There are, then, reasons to doubt that Claassen has sufficiently established the claim that either navigational agency or autonomy lies on a higher plane than other values. He may perhaps be forgiven for failing where Kant failed before him. Yet even if his ABC theory lacks this special justificatory status, his rich book has made a strong case for considering it as a hypothesis that we might have reason to accept on due reflection. Even without its 'transcendental' grounding, this book has given us an original capability theory with a well-elaborated conception of justice. 


\section{REFERENCES}

Anderson, Elizabeth S. 1999. "What Is the Point of Equality?" Ethics 109 (2): 287-337.

Korsgaard, Christine M. 2009. Self-Constitution: Agency, Identity, and Integrity. Oxford: Oxford University Press.

Rawls, John. 1999. A Theory of Justice. Revised edition. Cambridge, MA: Harvard University Press.

Rawls, John. 2001 Justice as Fairness: A Restatement. Edited by Erin Kelly. Cambridge, MA: Harvard University Press.

Smith, Michael. 2013 "A Constitutivist Theory of Reasons: Its Promise and Parts." Law, Ethics and Philosophy 1: 9-30.

Sen, Amartya K. 1980 "Equality of What?" In The Tanner Lectures on Human Values: Volume I, edited by Sterling M. McMurrin, 196-220. Salt Lake City, UT: University of Utah Press.

Sen, Amartya K. 2009. The Idea of Justice. Cambridge, MA: Harvard University Press.

Henry S. Richardson is Professor of Philosophy at Georgetown University. He was President of the Human Development and Capability Association from 2014-2016 and the Editor of Ethics from 2008-2018. His two most recent books are Moral Entanglements: The Ancillary-Care Obligations of Medical Researchers (Oxford, 2012) and Articulating the Moral Community: Toward a Constructive Ethical Pragmatism (Oxford, 2018). Contact e-mail: <henry.richardson@georgetown.edu> Website: <henrysrichardson.com> 